\title{
STATUS KEBERSIHAN MULUT DAN PERILAKU MENYIKAT GIGI ANAK SD NEGERI 1 MALALAYANG
}

\author{
${ }^{1}$ Randy Gopdianto \\ ${ }^{2}$ A. J. M Rattu \\ ${ }^{3}$ Ni Wayan Mariati \\ ${ }^{1}$ Kandidat Skripsi Program Studi Kedokteran Gigi Fakultas Kedokteran \\ ${ }^{2}$ Bagian Fisiologi Fakultas Kedokteran \\ ${ }^{3}$ Bagian Periodonsia Program Studi Kedokteran Gigi Fakultas Kedokteran \\ Universitas Sam Ratulangi Manado \\ Email: randygopdianto@yahoo.com
}

\begin{abstract}
Mouth is an ideal place for bacteria growth because of temperature, moisture and leftovers. Dental and oral hygiene is determined by leftovers (food debris), plaque, calculus and stains on the surface of the tooth. In an effort to maintain dental and oral hygiene, preferable given since elementary school age because that age is an ideal momentto train the child's ability to brush teeth. The purpose of this research is to know the status of dental and oral hygiene according to the habit of brushing teeth before going to bed at night in SD Negeri 1 Malalayang. Method of this study was descriptive study with cross-sectional design. Sample was taken by giving a questionnaire to find out the behavior of brushing teeth and do the OHIS examination according to Green and Vermillion to the students of class IV, V dan VI. Result of the study showed, the majority of respondents were female 35 people (64\%) and male 20 people (36\%), based on age of the respondents are aged 8 years 7 people (13\%), 9 years old 12 people (22\%), 10 years old 25 people (45\%) and 11 years old there were 11 people (20\%). Based on the assement of the examination OHIS, 35 respondents has goog result (64\%), 15 respondents had moderate result (27\%) and 5 respondents had poor result (20\%). Conclusion: Students in grade IV, V and VI have good dental and oral hygiene.
\end{abstract}

Keywords: oral hygiene status, brushing teeth behavior

\begin{abstract}
Abstrak: Mulut merupakan suatu tempat yang ideal bagi perkembangan bakteri karena temperatur, kelembapan dan sisa makanan. Kebersihan gigi dan mulut ditentukan oleh sisa makanan (food debris), plak, kalkulus, dan noda (stain) pada permukaan gigi. Dalam usaha menjaga kebersihan mulut sebaiknya diberikan sejak usia sekolah dasar karena usia tersebut merupakan saat yang ideal untuk melatih kemampuan anak termasuk menyikat gigi. Tujuan penelitian ini ialah untuk mengetahui status kebersihan mulut menurut kebiasaan menyikat gigi sebelum tidur malam pada anak di SD Negeri 1 Malalayang. Penelitian ini bersifat deskriptif dengan rancangan yang digunakan ialah cross sectional. Pengambilan sampel dengan cara memberikan kuesioner untuk mengetahui perilaku menyikat gigi dan melakukan pemeriksaan OHIS menurut Green and Vermillion pada siswa-siswi kelas IV, V dan VI. Hasil penelitian menunjukkan sebagian besar respoden berjenis kelamin perempuan 35orang (64\%) dan jenis kelamin laki-laki 20 orang (36\%). Berdasarkan usia terdapat responden umur 8 tahun 7 orang (13\%), umur 9 tahun sebanyak 12 orang (22\%), kemudian usia 10 tahun mempunyai 25 orang (45\%), dan umur 11 tahun terdapat 11 orang (20\%). Berdasarkan penilaian dari pemeriksaan OHIS sebanyak 35 responden (64\%) berkategori baik, 15 responden (27\%) berkategori sedang, dan berkategori buruk 5 responden (9\%). Simpulan: Siswa-siswi kelas IV, V dan VI memiliki kebersihan gigi dan mulut yang baik.
\end{abstract}

Kata kunci : status kebersihan mulut, perilaku menyikat gigi 
Mulut merupakan suatu tempat yang amat ideal bagi perkembangan bakteri, karena temperatur, kelembaban dan makanan yang cukup tersedia di sana. Bakteri inilah yang berpengaruh pada kesehatan gigi dan mulut. Kebersihan gigi dan mulut ditentukan oleh sisa makanan (food debris), plak, kalkulus material alba, dan noda (stain) pada permukaan gigi. ${ }^{1}$

Hasil Riset Kesehatan Daerah (RISKESDAS) tahun 2007 oleh Departemen Kesehatan RI menunjukkan prevalensi anak yang mengalami masalah kesehatan gigi dan mulut berdasarkan karakteristik umur adalah 5-9 tahun sebesar 21,6\%, umur 10-14 tahun sebesar $20,6 \%$ dan terjadi di pedesaan sebesar $24,4 \% .^{2}$

Dalam usaha menjaga kebersihan mulut faktor kesadaran dan perilaku pemeliharaan kebersihan gigi dan mulut personal.Hal ini begitu penting karena kegiatan yang dilakukan dirumah tanpa ada pengawasan dari siapapun, sepenuhnya tergantung dari pengetahuan, pemahaman, kesadaran serta kemauan dari pihak individu untuk menjaga kesehatan mulutnya. Untuk tujuan tersebut cara paling mudah dan umum dilakukan adalah dengan cara menyikat gigi secara teratur dan benar karena hal tersebut merupakan usaha yang dapat dilakukan secara personal. ${ }^{3}$

Pengetahuan kesehatan gigi dan mulut sebaiknya diberikan sejak usia dini, karena pada usia dini anak mulai mengerti akan pentingnya kesehatan serta larangan yang harus dijauhi atau kebiasaan yang dapat memengaruhi keadaan giginya. Pemberian pengetahuan kesehatan gigi dan mulut sebaiknya diberikan pada anak usia sekolah. Sekolah Dasar (SD) merupakan suatu kelompok yang sangat strategis untuk penanggulangan kesehatan gigi dan mulut. ${ }^{4}$

Usia sekolah dasar merupakan saat yang ideal untuk melatih kemampuan motorik seorang anak, termasuk di antaranya menyikat gigi. Potensi menyikat secara baik dan benar merupakan faktor yang cukup penting untuk pemeliharaan kesehatan gigi dan mulut. Berhasilnya pemeliharaan kesehatan gigi dan mulut juga dipengaruhi oleh faktor pengunaan alat, metode penyikatan gigi, serta frekuensi dan waktu penyikatan yang tepat. Kelompok anak usia sekolah dasar ini termasuk kelompok rentan untuk terjadinya kasus kesehatan gigi dan mulut, sehingga perlu diwaspadai atau dikelola secara baik dan benar. ${ }^{5}$

Penyikatan gigi pada anak dengan frekuensi yang tidak optimal dapat disebabkan karena anak tidak dibiasakan melakukan penyikatan gigi sejak dini oleh orang tua, sehingga anak tidak mempunyai kesadaran dan motivasi untuk memelihara kesehatan gigi dan mulutnya, keadaan tersebut memudahkan gigi anak terkena resiko penyakit gigi dan mulut. Sebanyak 89\% anak Indonesia di bawah 12 tahun menderita penyakit gigi dan mulut, kondisi itu akan berpengaruh pada derajat kesehatan dalam proses tumbuh kembang. 6,7

Perawatan gigi dan mulut pada masa anak-anak sangat menentukan kesehatan gigi dan mulut mereka pada tingkatan usia lanjut. Tindakan pencegahan yang bisa dilakukan adalah membersihkan mulut dengan menyikat gigi, flossing, dan pemeriksaan gigi secara teratur ke dokter gigi. Dari data sebesar 61,5 \% penduduk yang menyikat gigi tidak sesuai anjuran yaitu menyikat gigi hanya satu kali setelah bangun tidur, bahkan masih 16,5\% penduduk tidak menyikat gigi, sedangkan yang sesuai anjuran program yaitu menyikat gigi setelah makan pagi dan sebelum tidur hanya $21,9 \%{ }^{8}$

Berdasarkan latar belakang diatas penulis melakukan penelitian mengenai Status Kebersihan Mulut dan Perilaku Menyikat Gigi Anak SD Negeri 1 Malalayang, karena penelitian tersebut belum pernah dilakukan di SD Negeri 1 Malalayang khususnya mengenai kebersihan gigi dan mulut pada anakanak. 
BAHAN DAN METODE PENELITIAN

Jenis penelitian ini memakai penelitian deskrptif dengan pendekatan cross sectional study. Penelitian telah dilaksanakan di SD Negeri 1 Malalayang. Sampel penelitian ini siswa- siswi kelas IV, V dan VI berusia $8-11$ tahun yang bersekolah pagi di SD negeri 1 Malalayang. Jumlah sampel diperoleh dengan mengunakan Rumus Slovin, sebagai berikut:

$$
\mathrm{n}=\frac{\mathrm{N}}{\mathrm{N}(\mathrm{d})^{2}+1}
$$

Keterangan: $n=$ Jumlah sampel

$\mathrm{N}=$ Jumlah populasi

$\mathrm{d}=$ margin kesalahan 0,1

Berdasarkan rumus tersebut besar sampel yang diperoleh ialah sebagai berikut:

$$
\mathrm{n}=\frac{\mathrm{N}}{119(0,1)^{2}+1}=54,3=55 \text { sampel }
$$

Dengan demikian besar sampel yang digunakan berjumlah 55 responden.

Pengambilan sampel menggunakan metode total sampling yaitu dengan cara membagikan kuesioner kepada siswa-siswi kelas IV, V dan VI yang bersekolah pagi untuk mengetahui kriteria inklusi sebelum dijadikan sampel dan pengambilan sampel dengan cara melihat status kebersihan mulut melalui pemeriksaan langsung dirongga mulut dengan menggunakan explorer.Penilaiannya diukur dengan menggunakan indeks kebersihan gigi dan mulut atau Oral Hygiene Indeks Symplified (OHI-S) yang mengukur daerah permukaan gigi yang ditutupi oleh plak atau kalkulus. Pemeriksaan OHIS menurut Greene and Vermillion menetapkan gigi indeks yang digunakan ialah 4 gigi posterior dan 2 gigi anterior, kategori baik $(0,0-1,2)$, sedang $(1,3-3,0)$, buruk $(3,1-6,0)$. Pengolahan data dilakukan secara manual dan disajikan dalam bentuk distribusi frekuensi.

\section{HASIL PENELITIAN}

Subjek penelitian ini berdasarkan jenis kelamin siswa-siswi SD negeri 1 malalayang yang telah mengikuti pemeriksaan melalui kuesioner dan OHIS yaitu sebanyak 55 responden, dari 55 respenden terdapat 20 responden (36\%) berjenis kelamin laki-laki dan 35 responden (64\%) berjenis kelamin perempuan (Tabel 1).

Tabel 1. Distribusi subjek penelitian berdasarkan jenis kelamin

\begin{tabular}{ccc}
\hline Jenis kelamin & $\mathrm{n}$ & $\%$ \\
\hline Laki-laki & 20 & 36 \\
Perempuan & 35 & 64 \\
\hline Total & 55 & 100 \\
\hline
\end{tabular}

Subjek penelitian ini merupakan berdasarkan jenis kelamin yang dilihat dari usia responden yakni usia 8 tahun sampai 11 tahun, berdasarkan jenis kelamin dan usia terdapat 7 responden untuk usia 8 tahun yaitu laki-laki 2 responden (4\%) dan perempuan 5 responden (9\%), usia 9 tahun terdapat 12 responden terdiri dari laki-laki 
5 responden (9\%) serta perempuan 7 responden (13\%), kemudian usia 10 tahun mempunyai 25 responden yakni laki-laki 10 responden (18\%) dan perempuan 15 responden (27\%), untuk usia 11 tahun memiliki 11 responden dari jumlah lakilaki 3 responden (6\%) dan perempuan 8 responden (15\%) (Tabel 2).

Tabel 2. Distribusi subjek penelitian berdasarkan usia

\begin{tabular}{|c|c|c|c|c|c|c|c|}
\hline \multirow{3}{*}{$\begin{array}{l}\text { Umur } \\
\text { (tahun) }\end{array}$} & \multicolumn{7}{|c|}{ Total } \\
\hline & \multicolumn{2}{|c|}{ Laki-laki } & \multicolumn{2}{|c|}{ perempuan } & \multicolumn{3}{|c|}{ total } \\
\hline & $\mathrm{n}$ & $\%$ & $\mathrm{n}$ & $\%$ & & & $\%$ \\
\hline 8 & 2 & 4 & 5 & 9 & & & 3 \\
\hline 9 & 5 & 9 & 7 & 13 & 12 & 22 & \\
\hline 10 & 10 & 18 & 15 & 27 & 25 & 45 & \\
\hline 11 & 3 & 5 & 8 & 15 & 11 & 20 & \\
\hline Total & 20 & 36 & 35 & 64 & & 55 & 100 \\
\hline
\end{tabular}

Subjek penelitian ini merupakan status kebersihan mulut yang dilihat dari pemeriksaan OHIS dari seluruh subjek penelitian sebanyak 55 responden yang didapatkan dari hasil perhitungan OHIS, dari 55 responden subjek penelitian yang dinilai dari pemeriksaan OHIS terdapat 35 responden (64\%) dengan kategori baik, 15 responden (27\%) dengan kategori sedang dan 5 responden (9\%) dengan kategori buruk (Tabel 3).

Tabel 3. Distribusi subjek penelitian berdasarkan OHIS

\begin{tabular}{ccc}
\hline Kategori OHIS & $\mathrm{n}$ & $\%$ \\
\hline Baik & 35 & 64 \\
Sedang & 15 & 27 \\
Buruk & 5 & 9 \\
\hline Total & 55 & $100 \%$ \\
\hline
\end{tabular}

Subjek penelitian ini merupakan status kebersihan mulut melalui pemeriksaan OHIS pada 55 responden lakilaki dan perempuan. Terdapat14 responden laki-laki (25\%) dan 21 responden perempuan (39\%) dengan kriteria oral hygiene baik; 2 responden laki-laki (4\%) dan 13 responden perempuan (23\%) dengan kriteria oral hygiene sedang; dan 4 responden laki-laki (7\%) dan 1 responden perempuan (2\%) dengan kriteria oral hygiene buruk yakni (Tabel 4). 
Jurnal e-GiGi (eG), Volume 3, Nomor 1, Januari-Juni 2015

Tabel 4. Distribusi OHIS subjek penelitian berdasarkan jenis kelamin

\begin{tabular}{lcccccccc}
\hline \multicolumn{1}{c}{ Jenis } & \multicolumn{1}{c}{ Baik } & \multicolumn{2}{c}{ Sedang } & Buruk & \multicolumn{2}{c}{ Total } \\
\cline { 2 - 9 } Kelamin & $\mathrm{n}$ & $\%$ & $\mathrm{n}$ & $\%$ & $\mathrm{n}$ & $\%$ & $\mathrm{n}$ & $\%$ \\
\hline Laki-laki & 14 & 25 & 2 & 4 & 4 & 7 & 20 & 36 \\
Perempuan & 21 & 39 & 13 & 23 & 1 & 2 & 35 & 64 \\
\hline Total & 35 & 64 & 15 & 27 & 5 & 9 & 55 & 100 \\
\hline
\end{tabular}

Hasil pengisian kuesioner oleh 55 siswa-siswi dikelas IV, V dan VI di SD negeri 1 malalayang dari pengisian kuesioner, menunjukkan responden yang menyikat gigi dengan durasi kurang dari 2 menit sebanyak 11 responden (20\%) yakni jenis kelamin laki-laki berkategori OHIS baik 3 responden (5\%), kategori sedang dan buruk hanya 1 responden (2\%). Dan jenis kelamin perempuan berkategori baik 2 responden (4\%), berkategori sedang 4 responden (7\%). Responden yang menyikat gigi dengan durasi 2-5 menit sebanyak 37 responden (67\%) yakni jenis kelamin lakilaki berkategori OHIS baik 10 responden (18\%), kategori sedang 1 responden (2\%). Jenis kelamin perempuan berkategori baik 18 responden (33\%), kategori sedang 8 responden (14\%). dan responden yang tidak tahu berapa lama waktu yang mereka perlukan untuk menyikat gigi sebanyak 7 responden (13\%).

Frekuensi responden yang menyikat gigi 1 kali sehari sebanyak 4 responden (7\%) jenis kelamin laki-laki berkategori OHIS buruk 3 responden (5\%) dan jenis kelamin perempuan 1 responden (2\%). Responden yang menyikat gigi $2 \mathrm{x}$ kali sehari sebanyak 43 responden (78\%) yakni jenis kelamin laki-laki berkategori OHIS baik 12 responden (21\%), kategori sedang 1 responden (2\%) sedangkan jenis kelamin perempuan kategori baik 19 responden (35\%), kategori sedang 12 responden (21\%). Dan responden yang menyikat gigi lebih dari 2x sehari sebanyak 7 responden
(13\%) yakni jenis kelamin laki-laki kategori baik 2 responden (4\%), kategori sedang dan buruk hanya 1 responden (2\%).

Cara responden yang menyikat gigi secara memutar hanya 8 responden (14\%) jenis kelamin laki-laki kategori sedang 1 responden (2\%), kategori buruk 3 responden (5\%) dan jenis kelamin perempuan kategori baik 3 responden (6\%), kategori sedang 1 responden (2\%). Responden yang menyikat gigi secara maju-mundur sebanyak 3 responden (6\%) yakni jenis kelamin laki-laki kategori OHIS baik dan buruk hanya 1 responden (2\%). Gerakan kombinasi memiliki responden terbanyak yakni 44 responden (80\%) pada jenis kelamin laki-laki kategori OHIS baik 13 responden (23\%), kategori sedang 1 responden (2\%) dan pada jenis kelamin perempuan kategori baik 18 responden (33\%), kategori sedang 12 responden (21\%) (Tabel 5).

\section{BAHASAN}

Berdasarkan hasil pemeriksaan Oral Hygiene Indeks Simplified (OHIS) pada subjek penelitian sebanyak 55 responden, subjek berjenis kelamin perempuan memiliki responden terbanyak yakni 35 orang (64\%) sedangakan jenis kelamin laki-laki memiliki 20 responden (36\%). Penelitian ini menunjukkan bahwa perempuan lebih baik dalam menjaga kebersihan gigi dan mulut dibandingkan laki-laki.Hal ini didukung dengan penelitian Moallemi pada anak-anak 
sekolah di Iran, yang menyatakan anak perempuan memiliki status kebersihan mulut yang lebih baik daripada anak lakilaki. Keadaan ini ini disebabkan karena perempuan lebih baik dalam mempraktikan perilaku menjaga kebersihan mulut dibandingkan dengan laki-laki. ${ }^{9}$

Tabel 5. Distribusi gambaran perilaku menyikat gigi

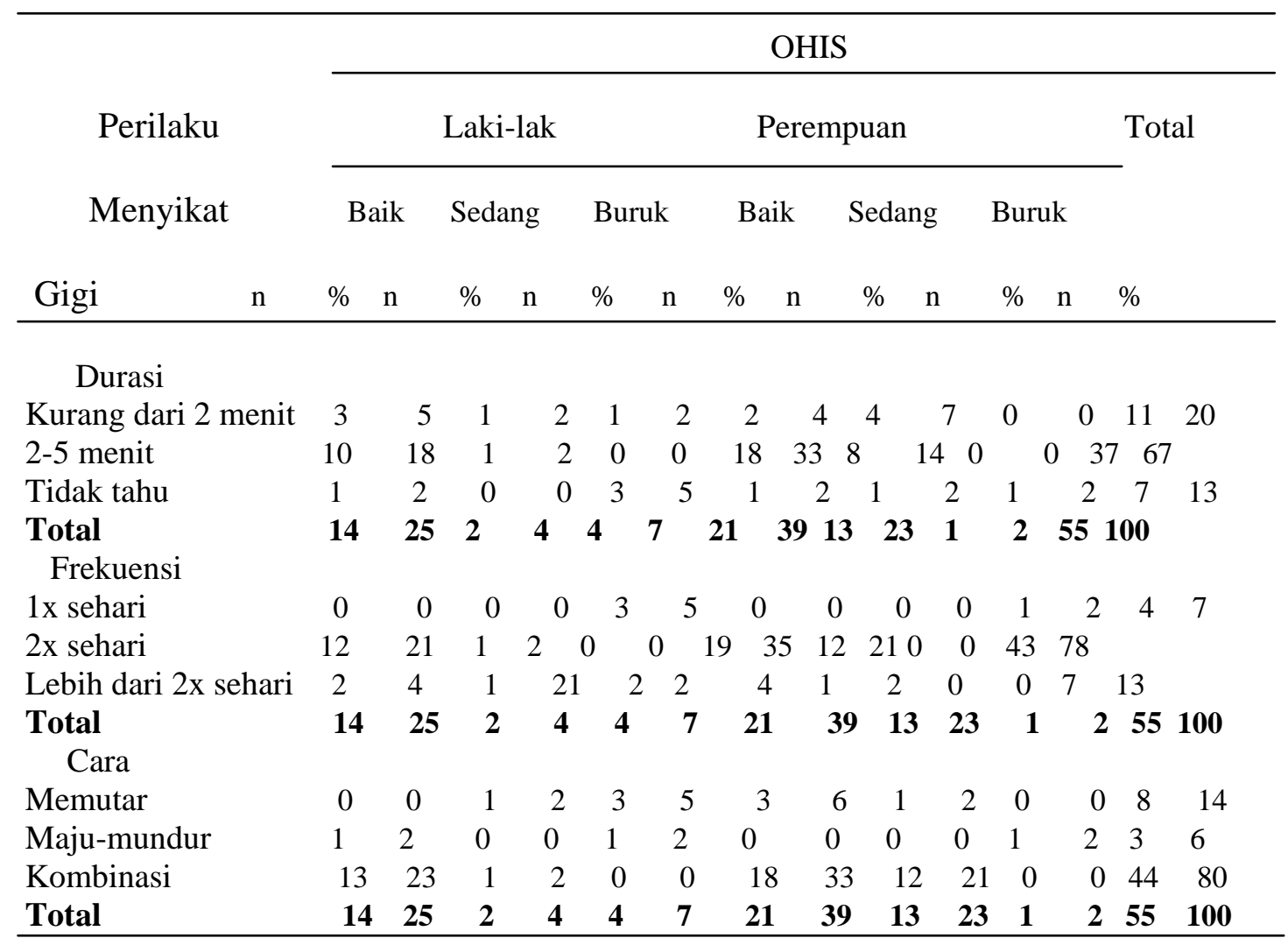

Hasil penelitian ini menunjukkan kelompok usia pada subjek penelitian, pada usia 8 tahun jenis laki-laki memiliki 2 responden (4\%) dan perempuan mempunyai 5 responden (9\%), untuk usia 9 tahun terdapat 12 responden yakni jenis kelamin laki-laki 5 responden (9\%) dan perempuan 7 responden (13\%), kemudian usia 10 tahun pada jenis kelamin laki-laki memiliki 10 responden (18\%) dan perempuan sebanyak 15 responden (27\%), usia 11 tahun mempunyai3 responden (5\%) pada jenis kelamin laki-laki dan 8 responden (15\%) perempuan. Hal ini menunjukan kelompok usia 10 tahun memiliki responden terbanyak dibandingkan usia lainnya yang dijadikan subjek penelitian dari siswa-siswi kelas IV, V dan VI.

Dari hasil penelitian pemeriksaan OHIS yang dilakukan secara langsung di rongga mulut secara keseluruhan pada subjek penelitian. Sebanyak 35 responden (64\%) memiliki kriteria kebersihan mulut yang baik, 15 responden (27\%) memiliki kriteria kebersihan mulut sedang dan 5 responden (9\%) memiliki kriteria kebersihan mulut yang buruk. Penelitian ini menunjukkan bahwa sebagian besar responden pada subjek penelitian mempunyai kebersihan gigi dan mulut yang baik, keadaan ini disebabkan karena responden telah mengetahui informasi menjaga kebersihan mulut dengan benar melalui penyuluhan dan media iklan. Hal ini didukung dengan penelitian tentang kebersihan mulut disekolah dasar yang dilakukan oleh Ristya Widi, perilaku membersihkan gigi dengan kategori sangat baik menduduki presentase 
tertinggi yaitu sebesar 57,6\% dengan total sampel 170 siswa, selanjutnya kategori baik sebesar $31.5 \%$ dengan jumlah sampel 93 siswa dan kategori sedang dengan presentase $10,8 \%$ pada 32 siswa. $^{3}$

Hasil penelitian ini juga menunjukan kebersihan mulut ( OHIS ) berdasarkan jenis kelamin pada 55 responden, untuk jenis kelamin laki-laki dengan kategori baik memiliki 14 responden (25\%), kategori sedang 2 responden (4\%) dan kategori buruk hanya 4 responden (7\%). Jenis kelamin perempuan memiliki 21 responden (39\%) untuk kategori baik, 13 responden (23\%) kategori sedang dan hanya 1 responden (2\%) untuk kategori buruk. Hal ini menunjukan jenis kelamin laki-laki dan perempuan memiliki kebersihan mulut yang baik dengan total 35 responden (64\%) dari 55 responden dalam subjek penelitian. Keadaan ini menunjukkan rata-rata responden pada jenis kelamin perempuan dan jenis kelamin laki-laki mempunyai OHIS yang baik, karena pengetahuan tentang menyikat gigi yang baik.Hal ini didukung oleh pustaka tentang semakin baik perilaku membersihkan gigi maka semakin baik tingkat kebersihan mulut. Hal ini sesuai dengan bahan pendapat Tarigan yang mengatakan bahwa mengosok gigi dengan teratur akan menyebabkan rongga mulut semakin bersih dan baik. ${ }^{3}$

Dari hasil penelitian ini juga terdapat 55 respoden yang dilihat kebersihan gigi dan mulut dari perilaku menyikat gigi melalui kuesioner (tabel 5). Dari data tabel 5 menunjukan responden yang menyikat gigi dengan durasi kurang dari 2 menit sebanyak 11 responden (20\%) yakni jenis kelamin laki-laki berkategori OHIS baik 3 responden (5\%), kategori sedang dan buruk hanya 1 responden (2\%). Dan jenis kelamin perempuan berkategori baik 2 responden (4\%), berkategori sedang 4 responden (7\%). Responden yang menyikat gigi dengan durasi 2-5 menit sebanyak 37 responden (67\%) yakni jenis kelamin lakilaki berkategori OHIS baik 10 responden (18\%), kategori sedang 1 responden (2\%). Jenis kelamin perempuan berkategori baik 18 responden (33\%), kategori sedang 8 responden (14\%). dan responden yang tidak tahu berapa lama waktu yang mereka perlukan untuk menyikat gigi sebanyak 7 responden (13\%).Data ini menunjukkan bahwa sebagian besar responden mengetahui durasi waktu yang diperlukan dalam menyikat gigi, keadaan ini disebabkan karena informasi mengenai durasi menyikat gigi sering diberikan pada saat penyuluhan dan walaupun sebagian responden belum mengetahui durasi waktu menyikat gigi karena sulit mempraktikan waktu saat menyikat gigi.Hasil ini sesuai anjuran beberapa dokter gigi yang mengatakan durasi yang baik menyikat gigi yaitu sekitar 2-5 menit. Hal ini didukung oleh kepustakaan mengenai penyikatan gigi dianjurkan selama 2 menit serta dilakukan secara sistematis supaya tidak ada bagianbagian yang terlampaui. ${ }^{10}$

Dari waktu dan durasi dapat dilihat juga frekuensi responden yang menyikat gigi 1 kali sehari sebanyak 4 responden (7\%) jenis kelamin laki-laki berkategori OHIS buruk 3 responden (5\%) dan jenis kelamin perempuan 1 responden (2\%). Responden yang menyikat gigi $2 \mathrm{x}$ kali sehari sebanyak 43 responden (78\%) yakni jenis kelamin laki-laki berkategori OHIS baik 12 responden (21\%), kategori sedang 1 responden (2\%) sedangkan jenis kelamin perempuan kategori baik 19 responden (35\%), kategori sedang 12 responden (21\%). Dan responden yang menyikat gigi lebih dari 2x sehari sebanyak 7 responden (13\%) yakni jenis kelamin laki-laki kategori baik 2 responden (4\%), kategori sedang dan buruk hanya 1 responden (2\%). Keadaaan ini disebabkan pengetahuan responden sudah baik mengenai frekuensi menyikat gigi karena faktor bimbingan orang tua dan informasi kesehatan. Hal ini didukung oleh kepustakaan yang mengatakan anjuran dokter gigi untuk menyikat gigi 2 kali sehari pada waktu setelah makan pagi dan sebelum tidur malam. ${ }^{11}$

Selain frekuensi menyikat gigi, hal yang paling penting dalam penyikatan gigi yaitu metode menyikat gigi. Cara responden yang menyikat gigi secara 
memutar hanya 8 responden (14\%) jenis kelamin laki-laki kategori sedang 1 responden (2\%), kategori buruk 3 responden (5\%) dan jenis kelamin perempuan kategori baik 3 responden (6\%), kategori sedang 1 responden (2\%). Responden yang menyikat gigi secara maju-mundur sebanyak 3 responden (6\%) yakni jenis kelamin laki-laki kategori OHIS baik dan buruk hanya 1 responden (2\%). Gerakan kombinasi memiliki responden terbanyak yakni 44 responden (80\%) pada jenis kelamin laki-laki kategori OHIS baik 13 responden (23\%), kategori sedang 1 responden (2\%) dan pada jenis kelamin perempuan kategori baik 18 responden (33\%), kategori sedang 12 responden (21\%). Dari hasil diatas metode kombinasi merupakan metode terbanyak yang digunakan oleh para responden, hal ini disebabkan banyaknya informasi pola penyikatan gigi yang didapatkan responden baik melalui penyuluhan yang diberikan disekolah maupun iklan kesehatan di media televise. Hal ini sesuai dengan kepustakaan mengenai teknik penyikatan dapat merupakan teknik kombinasi yang sering digunakan dari teknik-teknik yang ada. ${ }^{10}$

\section{SIMPULAN}

1. Perilaku menyikat gigi pada responden sudah baik dalam mempraktekkan durasi, frekuensi dan metode cara menyikat yang benar.

2. Status kebersihan mulut memiliki 35 responden (64\%) berkategori baik, berkategori sedang mempunyai 15 responden (27\%), dan yang berkategori buruk hanya 5 responden (9\%).

\section{SARAN}

Disarankan bagi Dinas Kesehatan agar dapat melakukan kerja sama dengan pihak sekolah melalui program-program peningkatan kesehatan gigi dan mulut anak, dan juga penyediaan sarana dan prasarana untuk menunjang pelaksanaan program tersebut dalam mempertahankan dan bahkan lebih meningkatkan status kebersihan gigi dan mulut.

1. Untuk pihak sekolah disarankan agar dapat berkerja sama dengan dinas kesehatan dalam upaya lebih meningkatkan status kebersihan gigi dan mulut kedepan.

2. Untuk institusi pendidikan dapat melakukan penelitian lebih lanjut tentang status kebersihan gigi dan mulut menurut kebiasaan menyikat gigi sebelum tidur malam di sekolah menengah pertama.

3. Untuk masyarakat melalui hasil penelitian ini dapat berfungsi menambah pengetahuan menjaga kebersihan gigi dan mulut sejak usiadini, dan menambah pengetahuan kapan serta waktu menyikat gigi yang baik dan benar.

\section{DAFTAR PUSTAKA}

1. Hadnyanawati H. Hubungan kebersihan gigi dan mulut dengan gingivitis pada siswa sekolah dasar kelas $\mathrm{V}$ di kabupaten jember. Jakarta. JKGUI 2002; 9(2). p.10.

2. Kurnia ES, Ulfiana E, Dian P. Pengaruh pendidikan kesehatan gosok gigi dengan metode permainan simulasi ular tangga terhadap perubahan pengetahuan, sikap, dan aplikasi tindakan gosok gigi anak usia sekolah di SD wilayah Parow Ngawi. Indonesian Journal of Community Health Nursing. ISSN2012. Vol;1(1).p. 1-2.

3. Widi RE. Hubungan perilaku membersihkan gigi terhadap tingkat kebersihan mulut siswa sekolah dasar negeri diwilayah kerja puskesmas Gladak Pakem Kabupaten Jember. Jakarta. JKGI 2003; 10 (3). p. 9-14.

4. Pradita I, Widodorini T, Rachmawati R. Perbedaan tingkat pengetahuan kesehatan gigi dan mulut pada siswa sekolah dasar di kota (SDN Purwantoro 1 Malang) dan di desa (SDN Sukopuro 3 Kabupaten Malang). [cited] 2014 Mar 06. Available from URL: http://journal.unnes.ac.id/nju/index.php /kemas/article/download/1757/1952. 
5. Ilyas M, Putri IN. Efek penyuluhan metode demonstrasi menyikat gigi terhadap penurunan indeks plak gigi pada murid sekolah dasar. Makassar. Dentofasial 2012. ISSN: 1412-8926. Vol: 11. p: 9192.

6. Chemiawan E, Riyanti E, Tjahyaningrum SN. Prevalensi nurshing mouth caries pada anak usia 15-60 bulan berdasarkan frekuensi penyikatan gigi di posyandu desa Cileunyi Wetan Kecamatan Cileunyi Kabupaten Bandung Tahun 2004. [cited] $2013 \mathrm{Mar}$ 15. Available from URL: http://resources.unpad.ac.id/unpadconte nt/uploads/publikasi_dosen/PREVALE NSI\%20NURSING\%20MOUTH\%20C ARIES\%20PADA\%20ANAK\%20USI A\%2015.pdf

7. Hastuti S, Andriyani A. Perbedaan pengaruh pendidikan kesehatan gigi dalam meningkatkan pengetahuan tentang kesehatan gigi pada anak di SD negeri 2 sambi kecamatan samba kabupaten boyolali. GASTER Vol;
7(2). 2010. p: 625.

8. Tirahiningrum $P$, Nugraeni $Y$, Sukma CM. Hubungan pola menyikat gigi dengan indeks DMF-T pada siswa kelas VI Madrasah Ibtidaiyah Nahtadul Ulama (MINU) kecamatan Blimbing Malang. [cited] 2014 Mar 13. Available from URL: http://old.fk.ub.ac.id/artikel/id/filedown load/gigi/Majalah\%20cempaka.pdf

9. Moallemi ZS. Oral Health among Iranian preadolescents: a school-based health education intervention. Department of Oral Public Institute of Dentistry Faculty of Medicene University of Helsinki; Helsinki Finland. 2011

10.Ariningrum R. Beberapa cara menjaga kebersihan gigi dan mulut. Cermin dunia kedokteran. Jakarta. 2000. p: 4950

11. Yanti GN, Natamiharja L. Pemilihan dan pemakaian sikat gigi pada murid-murid SMA di kota medan. Dentika dental journal. 2005. Medan. Vol; 10(1). p:2830 